\title{
ANÁLISE DE FLUXO PROCESSUAL DE FEMINICÍDIOS: REFLEXÕES PARA O APERFEIÇOAMENTO DA PERSECUÇÃO PENAL
}

\author{
ANALYSIS OF PROCEDURAL FLOW OF FEMICIDES: \\ REFLEXIONS TO IMPROVE THE PROSECUTION
}

\author{
Thiago Pierobom de Ávila ${ }^{1}$ \\ Marcela Novais Medeiros ${ }^{2}$ \\ Marcus Vinicius Teixeira Borba ${ }^{3}$ \\ Thais Quezado Soares Magalhães ${ }^{4}$ \\ Andrea Simoni de Zappa Passeto ${ }^{5}$
}

RESUMO.

Esta pesquisa tem o objetivo de avaliar a efetividade da persecução penal de 34 processos judiciais de feminicídio consumado no Distrito Federal - DF, em contexto de violência doméstica e familiar contra a mulher, nos anos de 2016 e 2017, à luz das diretrizes nacionais. Utilizou-se metodologia de análise longitudinal prospectiva com utilização de método misto quantitativo e qualitativo, com recurso à análise temática. Complementou-se o corpus com análise dos prontuários médicos da vítima na rede pública de saúde e entrevistas semiestruturadas a familiares das vítimas. Analisaramse as variáveis de tempo e resultado processual. Verificou-se elevada taxa de condenação entre os processos julgados em plenário do júri (95,6\% dos julgados), com pena média de 20 anos de reclusão, em tempo médio até o julgamento de 694 dias e com $91 \%$ dos réus presos preventivamente durante o julgamento. Todavia, em nenhum caso houve indenização em favor de familiares da vítima na sentença condenatória. Apontam-se áreas de aperfeiçoamento para a investigação criminal e atuação processual com perspectiva de gênero: necessidade de juntada de antecedentes do agressor, entrevistas a familiares, realização e juntada de perícias, especialmente estudos psicossociais, proteção aos familiares, e não uso de argumentos discriminatórios.

\footnotetext{
${ }^{1}$ Doutor em Ciências Jurídico-Criminais pela Universidade de Lisboa, com Pós-Doutorado em Criminologia pela Universidade Monash. Professor Associado do programa de pós-graduação em Direito do UniCEUB, Professor dos programas de pós-graduação lato sensu da FESMPDFT e do IDP. Pesquisador integrado do Centro de Investigação de Direito Penal e Ciências Criminais da Universidade de Lisboa e do Gender and Family Violence Prevention Centre da Universidade Monash, Austrália. Promotor de Justiça do MPDFT. Afiliação: Centro Universitário de Brasília - UniCEUB, DF; Universidade de Lisboa, Portugal; Monash University, Melbourne, Austrália. Lattes: http://lattes.cnpq.br/0140889347238140. ORCID:http://orcid.org/0000-0001-8163-5806. Email:thiago.pierobom@hotmail.com

${ }^{2}$ Doutora em Psicologia Clínica e Cultura pela Universidade de Brasília (2015). Membro do Núcleo de Estudos de Gênero e Psicologia Clínica - NEGENPSIC da Universidade de Brasília.Psicóloga do CEPAV - Secretaria de Estado de Saúde do Distrito Federal, Brasília/DF. Afiliação:Núcleo de Estudos de Gênero e Psicologia Clínica NEGENPSIC da Universidade de Brasília, DF. Lattes:http://lattes.cnpq.br/2357325410914884. ORCID:https://orcid.org/0000-0002-0356-6419. E-mail:marcelanovaismedeiros@yahoo.com.br

${ }^{3}$ Mestre em Matemática pela Universidade de Brasília (2004).Bacharel em Matemática (2002) e em Estatística (2014) pela Universidade de Brasília..Analista de Estatística do Ministério Público da União, Brasília/DF. Afiliação:Ministério Público da União, Brasília/DF. Lattes:http://lattes.cnpq.br/1356259888566150. ORCID:https://orcid.org/0000-0002-4785-0147. E-mail:marcus.borba@mpdft.mp.br>

${ }^{4}$ Mestre em Direitos Humanos pela University College London - UCL (2016).Chefe dos Núcleos de Direitos Humanos do MPDFT, Brasília/DF. Afiliação:Ministério Público do Distrito Federal e Territórios, Brasília/DF Lattes: http://lattes.cnpq.br/5031286613076082 ORCID:https://orcid.org/0000-0002-0995-6557 E-mail: thaisqsm@ hotmail.com

${ }^{5}$ Especialista em impactos da violência na saúde pela FIOCRUZ (2018).Médica do NEPAV - Secretaria de Estado de Saúde do Distrito Federal, Brasília/DF. Afiliação:Secretaria de Estado de Saúde do Distrito Federal, Brasília/DF Lattes:http://lattes.cnpq.br/8947710527174280 ORCID:https://orcid.org/0000-0002-6890-1759 E-mail:andrea. passeto@saude.df.gov.br
} 
Palavras-chave: Pesquisa documental. Feminicídio. Fluxo processual. Efetividade. Perspectiva de gênero.

\begin{abstract}
.
This study aims to evaluate the effectiveness of the prosecution of 34 court cases of femicide in the Federal District, Brazil, in the context of domestic and family violence, between 2016 and 2017, considering the national guidelines. It uses a mixed quantitative and qualitative method, specially thematic analysis. The research was further complemented with the analysis of the victim's health files and of a semistructured interview with the victim's relatives. It analyzed procedural time and results. There is a high rate of conviction on jury trials $(95,6 \%)$, with the average punishment being 20 years imprisonment; the average time from the commitment of the crime to the trial is 694 days, and $91 \%$ of defendants remain under provisional arrest until the trial. Nevertheless, in no case the conviction sentence granted indemnity for the victim's relatives. This research identifies areas to improve investigation and prosecution with gender perspective, as: considering criminal background on gender violence, interviewing relatives, ordering and attaching experts' reports, especially psychosocial reports, promoting protection of relatives and avoiding discriminatory arguments on trial.
\end{abstract}

Keywords. Documental research. Femicide. Procedural stream. Effectiveness. Gender perspective.

\title{
INTRODUÇÃO
}

O presente artigo apresenta os resultados de pesquisa documental com recorte longitudinal prospectivo sobre os processos judiciais de feminicídio consumado, praticados em contexto de violência doméstica e familiar contra a mulher (VDFCM), no Distrito Federal (DF), nos anos de 2016 e 2017, com análise de fluxo seguida de problematização sobre as áreas de possível aperfeiçoamento à atuação processual do Ministério Público perante o Tribunal do Júri, com utilização de método misto quantitativo e qualitativo.

A violência contra a mulher é uma grave violação de direitos humanos de dimensões epidêmicas (OMS, 2002). De 2010 a 2015, uma média de 64.000 mulheres foram mortas a cada ano no mundo (SMALL ARMS SURVEY, 2016). Apenas no ano de 2017 ocorreram 4.936 homicídios de mulheres no Brasil, uma média de 13 assassinatos por dia (IPEA; FBSP, 2019).

O feminicídio foi tipificado no Brasil pela Lei n. 13.104/2015, como uma forma de qualificadora do homicídio (Código Penal, art. 121, § $2^{\circ}$, inciso VI, c/c § $2^{\circ}$-A). Uma das principais finalidades da criminalização do feminicídio é trazer "lentes de gênero" para os julgamentos das mortes de mulheres em razão da discriminação sexista (ÁVILA, 2018). Pesquisa realizada no DF antes da criminalização do feminicídio, relativa aos homicídios de mulheres em contexto de VDFCM durante os anos de 2006-2011, demostrou um reconhecimento da circunstância agravante da VDFCM (Código Penal, art. 61, inciso II, alínea “f”, introduzido pela Lei n. 11.340/2006) em 
apenas $28 \%$ dos casos, indicando a possível não consideração destes contextos no julgamento (DINIZ, 2015). O debate público tem se voltado à avaliação de como o sistema de justiça tem respondido ao feminicídio. O presente trabalho, além de aportar elementos que possam aprimorar essas respostas, busca contribuir igualmente para a transparência institucional do sistema de justiça.

A pesquisa se utiliza da metodologia de análise documental (GODOY, 1995) com o recorte institucional e temporal correspondente à análise de todos os processos judiciais com a incidência penal de feminicídio consumado (Código Penal, art. 121, § 2º inciso VI), nos anos de 2016 e 2017 no DF, conforme registros de ocorrências policiais da Polícia Civil do DF (Sistema Millenium), com cruzamento com as informações constantes do sistema de informática do Ministério Público (Sistema SisproWeb).

O levantamento preliminar localizou um total de $44 \operatorname{casos}^{6}$, sendo providenciadas as cópias dos autos e realizada a sua leitura integral. Dez casos foram excluídos do universo da pesquisa porque, apesar de a polícia ter partido da hipótese inicial de feminicídio, o curso das investigações não produziu prova de se enquadrar no recorte da pesquisa (caso de VDFCM) ${ }^{7}$. A pesquisa sobre o histórico de violência entre as partes foi complementada com análise dos prontuários médicos da vítima na rede pública de saúde, mediante parceria com o Núcleo de Estudos, Prevenção e Atenção às Violências da Secretaria de Saúde (NEPAV/SES) do DF, bem como com entrevista semiestruturada a familiares das vítimas em $19 \operatorname{casos}^{8}$. A pesquisa foi aprovada por comitê de ética (Parecer n. 3.070.767, CEP/UnB.).

\footnotetext{
${ }^{6}$ Os sistemas informaram inicialmente, em junho de 2018, a existência de 40 casos. Ao final da análise destes casos, em fevereiro de 2020, realizou-se nova pesquisa, e verificou-se a inclusão de mais quatro casos, que foram igualmente incluídos no universo da pesquisa e analisados.

${ }^{7}$ Dois casos foram sumariamente excluídos da amostra por não se enquadrarem no recorte: um era de tentativa de feminicídio, outro era de feminicídio consumado praticado fora do DF. Em dois casos o autor era adolescente, um caso não houve esclarecimento da autoria, em três casos aparentemente não se tratava de morte violenta intencional, mas mesmo assim a polícia estava investigando o caso como possível feminicídio (dois suicídios e uma de morte por AVC com histórico de violências anteriores), e um caso era de morte de mulher durante um ritual religioso sem autoria esclarecida. Finalmente, um caso excluído era relativo à morte de profissional do sexo por cliente imediatamente após o programa e sem prova de prévio relacionamento, em que a polícia inicialmente capitulou como feminicídio, mas o Ministério Público não incluiu esta qualificadora da denúncia. Esclarece-se que um dos casos incluídos na amostra era de uma relação ambígua, pois o agressor argumentava que a vítima era profissional do sexo, mas amigas dela informavam que ele insistia em ter um relacionamento afetivo com ela, sendo a morte praticada após a vítima ir à casa do réu e subtrair sua carteira; a denúncia considerou o caso como feminicídio na modalidade de menosprezo ou discriminação à mulher, pelo histórico de stalking; este caso foi incluído na amostra, pela proximidade com os demais casos de perseguição decorrente de prévia relação íntima. O presente recorte da pesquisa não afasta a relevância de o sistema de justiça ter mais sensibilidade para reconhecer os demais casos de feminicídio fora do contexto de VDFCM, por menosprezo ou discriminação à condição de mulher (ver crítica em: PASINATO, 2011).

${ }^{8}$ Em dois casos já havia nos autos detalhado estudo psicossocial, pelo que se considerou desnecessária a entrevista. Em quatro casos não havia informações que permitissem identificar possíveis familiares. Em nove casos tentouse contato com familiares, mas estes não aceitaram participar da entrevista. Dentre as 19 entrevistas realizadas, 11 foram de forma presencial e 8 por telefone. As entrevistas foram gravadas e posteriormente transcritas para análise, com exceção de duas, em que as entrevistadas não autorizaram a gravação, havendo apenas a transcrição das anotações do diálogo pela entrevistadora.
} 
A análise dos 34 casos que configuram o universo desta pesquisa teve dupla perspectiva, uma quantitativa de análise de fluxo do sistema de justiça (OLIVEIRA; MACHADO, 2018) e outra qualitativa de análise temática (BRAUN; CLARKE, 2006) quanto aos pontos de possível aperfeiçoamento da persecução penal, especificamente em relação à atuação da investigação criminal e atuação processual do Ministério Público. Na análise quantitativa, mapeou-se as variáveis de tempo e resultado em relação aos marcos de prisão em flagrante, conclusão da investigação criminal/denúncia, pronúncia e julgamento plenário pelo tribunal do júri. Na análise qualitativa, a partir da leitura exaustiva do material documental, buscou-se codificar os aspectos mais relevantes dos dados; esses códigos foram agrupados em temas e subtemas (BRAUN; CLARKE, 2006), que permitiram a compreensão dos aspectos investigativos e procedimentais dos casos de feminicídios. Utilizou-se como referencial teórico as diretrizes de investigação criminal e processamento com perspectiva de gênero (ONU MULHERES; BRASIL, 2016; BRASIL et al., 2016; ÁVILA, 2016; DISTRITO FEDERAL, 2017a; TÁVORA; ÁVILA, 2019; BRASIL, 2019). O marco final da atualização do andamento processual foi março de 2020.

$\mathrm{O}$ artigo abordará inicialmente os antecedentes político-criminais da criminalização do feminicídio na América Latina e Brasil, bem como as atuais diretrizes quanto à efetividade da persecução penal do feminicídio. Em seguida, será exposto o resultado quantitativo da análise de fluxo processual, sempre que possível realizando-se a comparação com pesquisa anterior, sobre o fluxo processual dos homicídios de mulheres em contexto de VDFCM no DF durante os anos de 2006-2011 (DINIZ, 2015). Finalmente, serão discutidos temas específicos extraídos da análise qualitativa dos processos para o aperfeiçoamento da investigação criminal e da atuação processual com perspectiva de gênero, inclusive com a formulação de recomendações de boas práticas na persecução penal do feminicídio. Será feita referência a alguns casos, com o uso de nomes fictícios das vítimas, exceto quando houver referência a dados dos registros de saúde, em que não haverá qualquer identificação.

\section{A criminalização do feminicídio enquanto instrumento de aperfeiçoamento da atuação do sistema de justiça criminal}

\subsection{Os antecedentes legislativos: nomear como uma estratégia política}

Apesar de a expressão feminicídio ter uso eventual na literatura inglesa do século XIX, o termo foi recuperado por Diana Russel em 1976 no Tribunal Internacional de Crimes contra as Mulheres (RUSSEL, 1992). Ela considerava "femicídio" (femicide) a morte de uma mulher pelo fato de ser mulher.

Desde os anos 1990, a expressão foi utilizada no contexto Latino-Americano como uma categoria teórica e política para descrever as mortes de mulheres por razões de discriminação de 
gênero. O termo femicide foi traduzido ao espanhol como feminicídio pela feminista e antropóloga mexicana Marcela Lagarde (2006).

A expressão ganhou força no contexto mexicano após os incidentes em Ciudad Juarez, uma cidade na fronteira com os EUA, vizinha da cidade texana de El Paso. Durante os anos 1990 uma elevada quantidade de mulheres foi morta nesta cidade, em contexto de agressões físicas, violência sexual coletiva, tortura e desaparecimentos, indicando que se tratavam de crimes de ódio. No período de 15 anos, houve em Juarez cerca de 400 mortes não esclarecidas e aparentemente sem objetivos (LEAL, 2008).

Em Cidade Juarez havia um número significativo de homens envolvidos no tráfico de drogas e na facilitação de imigração ilegal aos EUA, o que criou um ambiente de intensa cultura machista. Durante os anos 1990, diversas indústrias americanas instalaram filiais na cidade (conhecidas como maquiladoras). Estas indústrias preferiam contratar mulheres jovens, o que ensejou que as mulheres adquirissem independência econômica e passassem a circular mais pelos espaços públicos. A combinação de um ambiente sexista com mulheres desafiando a ordem de gênero levou a assédios seguidos de diversos confrontos violentos entre homens e mulheres. A natureza brutal das mortes indicava um componente disciplinar de punição às mulheres pela violação dos estereótipos de gênero (ROMERO, 2014). Diversos corpos de mulheres foram localizados em campos de algodão na área rural de Juarez, o que levou as mortes a serem conhecidas como "os casos do campo algodoeiro" (LEAL, 2008; PASINATO, 2011).

Diversos agentes públicos eram corruptos e negligenciaram a investigação destes casos (LAGARDE, 2006). Estas mortes foram associadas à persistente falha das autoridades públicas em preveni-las. Parte desta falha estava ligada à discriminação às vítimas, rotuladas como prostitutas ou envolvidas no tráfico de drogas. Neste contexto, as mães das vítimas criaram organizações para recuperar os corpos de suas filhas e promover a punição pelos crimes (LEAL, 2008). O movimento social levou à constituição de uma comissão parlamentar de inquérito de abrangência nacional, que deu visibilidade a mais de 6.000 assassinatos de mulheres por razões ligadas à sua condição de mulher (SEGATO, 2006).

O caso mexicano foi levado à Corte Interamericana de Direitos Humanos (CIDH, 2009), no caso Gonzalez e outras vs. México, tendo a corte reconhecido que as mortes daquelas mulheres derivavam da discriminação de gênero, configuravam grave violação de direitos humanos, e exigiam intervenções eficientes do Estado de prevenção e promoção de adequada responsabilização.

Após as discussões parlamentares no México e o acionamento da CIDH, a criminalização do feminicídio tornou-se uma tendência Latino-Americana. 16 países deste eixo global realizaram reformas legislativas semelhantes, seja criando um crime autônomo, seja na forma de uma 
qualificadora ou causa de aumento da pena, usando a expressão femicídio ou feminicídio (MACHADO, 2015; ÁVILA, 2018). A expressão femicide foi reconhecida em nível internacional em uma resolução da Assembleia Geral das Nações Unidas (ONU, 2014), que recomendou que as legislações nacionais deveriam punir as mortes de mulheres e meninas derivadas das relações de gênero, bem como criar mecanismos para prevenir e investigar estas formas de violência de gênero.

No Brasil, a criminalização do feminicídio seguiu recomendação da Comissão Parlamentar Mista de Investigação da violência doméstica. O relatório final desta comissão afirmou:

O feminicídio é a instância última de controle da mulher pelo homem: o controle da vida e da morte. Ele se expressa como afirmação irrestrita de posse, igualando a mulher a um objeto, quando cometido por parceiro ou ex-parceiro; como subjugação da intimidade e da sexualidade da mulher, por meio da violência sexual associada ao assassinato; como destruição da identidade da mulher, pela mutilação ou desfiguração de seu corpo; como aviltamento da dignidade da mulher, submetendo-a a tortura ou a tratamento cruel ou degradante. (BRASIL, 2013, p. 1003).

Segundo Segato (2006), a categorização do feminicídio objetiva denunciar a dimensão política das mortes das mulheres que resultam do controle patriarcal e do poder punitivo associado à masculinidade. Nas relações íntimas, quando uma mulher decide romper a relação, isso é considerado uma ofensa à virilidade do homem, representa não apenas desobediência, mas o questionamento de seu papel como provedor e mesmo sua performance sexual (MACHADO, 2019). Desafiar a autoridade do homem nas relações de família possui o mesmo resultado ofensivo. Esta mensagem implícita insulta a virilidade, de forma que a ordem de gênero exige que o homem exerça um poder disciplinar sobre a mulher para reafirmar sua honra (PASINATO, 2011; ROMERO, 2014). A ordem de gênero impõe um lugar social aos corpos femininos e legitima que homens controlem de forma disciplinar esta subserviência. Assim, a violência de gênero pode evoluir de humilhações, dor, privação de bens, agressões, até o ápice que é a morte. O feminicídio é um crime de poder, por ser motivado por razões de discriminação de gênero, tendo paralelismo com o racismo, a homofobia e a xenofobia.

Nesse sentido, afirmam Silva, Manso e Pinheiro (2019, p. 116):

\begin{abstract}
A maior expressão desta deterioração [do bem-estar das mulheres] se materializa no feminicídio e nos danos colaterais que eles provocam, pois o assassinato de uma mulher não é um fato que efeta exclusivamente a vítima, antes afeta todos os níveis, o nível familiar, institucional e cultural, sendo sua normalização cultural um dos principais problemas ante o qual nos encontramos.
\end{abstract}

Quando um homem pratica o feminicídio, ele está restabelecendo sua virilidade e reafirmando a vigência das normas de gênero, indicando sua execução como inevitável (ÁVILA, 2018). O fato de o corpo social muitas vezes compartilhar destes valores sexistas contribui para a impunidade, uma vez que gera a invisibilidade social dos crimes, a negligência na investigação e 
absolvições com a utilização de teses exculpantes de "legítima defesa da honra" ou de privilégio de “crime passional". A impunidade reafirma a normalidade das mortes, usualmente culpabilizando a vítima. Como afirmam Nielsson e Delajustine (2020, p. 342), as violências derivadas das relações de gênero "possuem uma dimensão pública, e, portanto, política, que funcionam como formas de estruturação de uma pedagogia da crueldade, que sustentaria espaços de poder, domínio e soberania eminentemente masculinos". Portanto, nomear o feminicídio é uma forma de enxergar e dar visibilidade à matança das mulheres, fomentando melhor compreensão de suas causas e fortalecendo a demanda de políticas públicas de prevenção (DINIZ et al., 2015; MACHADO, 2019).

\subsection{Diretrizes de efetividade na persecução penal do feminicídio}

Sobre os objetivos da criminalização do feminicídio, afirma Ávila (2018, p. 190):

A criminalização do feminicídio busca usar a legislação para promover a conscientização pública, facilitar políticas públicas de prevenção, produzir melhores estatísticas, promover melhor acolhimento em juízo às sobreviventes ou vítimas secundárias, evitar o uso de argumentos de "defesa da honra" e promover adequada responsabilização pela violência contra as mulheres.

Assim, é a própria lei que estabelece que estas mortes de mulheres não são menos importantes nem aceitáveis, favorecendo à não tolerância dos tradicionais argumentos jurídicos que as invisibilizavam. Com as novas lentes, o ciúme deixa de significar amor exacerbado para significar um inaceitável sentimento de posse e controle.

Um dos aspectos relevantes da criminalização do feminicídio é elevar a qualidade dos dados estatísticos (PASINATO, 2011). De acordo com Quiñones (2017), contabilizar as mortes de mulheres na América Latina é ainda um desafio, pois a maioria dos dados relativos não são desagregados por sexo. A produção de estatísticas de qualidade é essencial para esclarecer os padrões da violência contra as mulheres e desenvolver políticas baseadas em evidências. Em muitos países, a criminalização do feminicídio tem sido uma estratégia para fomentar registros criminais mais fiáveis (CEPAL, 2015). Por exemplo, no Brasil, a definição legal de feminicídio levou à eleição deste crime para meta da Estratégia Nacional de Justiça e Segurança Pública - ENASP de $2016^{9}$. Durante o primeiro ano da nova legislação (de 15 de março de 2015 a 15 de março de 2016), houve 3.818 casos de feminicídio anotados nos sistemas do Ministério Público em todo o Brasil,

\footnotetext{
9 “A Estratégia Nacional de Justiça e Segurança Pública - Enasp, foi constituída em 22 de fevereiro de 2010, por ato do Ministro de Estado da Justiça, do Presidente do Conselho Nacional do Ministério Público e do Presidente do Conselho Nacional de Justiça. Tem como o objetivo de planejar e implementar a coordenação de ações e metas nas áreas de justiça e segurança pública, em âmbito nacional, que exijam a conjugação articulada de esforços dos órgãos envolvidos". Informação disponível em: <https://www.novo.justica.gov.br/sua-seguranca/segurancapublica/enasp> Acesso em: 21 maio 2020.
} 
que levaram a 2.686 inquéritos policiais e, no final de 2016, 52,8\% dos casos tiveram ajuizamento de denúncia, 3,3\% foram arquivados, 3,2\% desclassificados para crimes menos graves, e 40,6\% permaneceram sob investigação (BRASIL, 2016). Neste relatório, o DF teve o maior percentual de denúncias (90,9\% dos inquéritos), enquanto Sergipe teve o menor (4,7\%).

Pesquisa no DF anterior à criminalização do feminicídio (DINIZ, 2015) destacou a dificuldade para esclarecer o quantitativo de homicídios praticados em contexto de VDFCM. Para obter a informação, foi necessário analisar os laudos do Instituto Médico Legal (IML) de todos os homicídios de mulheres e, em seguida, todos os processos, para então constatar que $35 \%$ destas mortes ocorreram em contexto de VDFCM. Para a atual pesquisa, a construção do acervo documental foi menos onerosa, já que a informação constava dos registros informatizados da PCDF e do MPDFT. Portanto, neste aspecto, a criminalização favoreceu à produção de dados estatísticos. Ainda que haja risco residual de eventual subnotificação e sejam necessárias cautelas especiais para a conferência periódica dos dados ${ }^{10}$.

No âmbito do direito internacional, há um "dever de atuação devida" (due diligence) previsto no art. 7, itens "b" e "e" da Convenção de Belém do Pará (BRASIL, 1996), que estabelece:

Art. $7^{\circ}$. Os Estados Partes condenam todas as formas de violência contra a mulher e convêm em adotar, por todos os meios apropriados e sem demora, políticas destinadas a prevenir, punir e erradicar tal violência e a empenhar-se em: [...]

b) agir com o devido zelo para prevenir, investigar e punir a violência contra a mulher; [...]

d) adotar medidas jurídicas que exijam do agressor que se abstenha de perseguir, intimidar e ameaçar a mulher ou de fazer uso de qualquer método que danifique ou ponha em perigo sua vida ou integridade ou danifique sua propriedade; $[\ldots]$

A CIDH (2009) igualmente reconhece o dever de devida diligência na investigação e processamento do feminicídio. Uma das formas de concretizar este dever de diligência na promoção da responsabilização dos agressores é a criação de diretrizes e protocolos específicos para profissionais do sistema de justiça (SEGATO, 2006; ÁVILA, 2018).

Nessa linha, alguns documentos nacionais procuram fomentar diretrizes de atuação aos profissionais do sistema de justiça para contexto de feminicídio, incorporando esta perspectiva crítica à investigação e processamento dos casos de feminicídio (ONU MULHERES; BRASIL, 2016; BRASIL, 2019 e 2020) ou ainda para os casos genéricos de VDFCM no âmbito da Lei Maria da Penha (BRASIL et al., 2016). No DF, há um guia de boas práticas aos Promotores de Justiça do júri (ÁVILA, 2016) e um procedimento operacional padrão pela Polícia Civil para a investigação

\footnotetext{
${ }^{10}$ Ver comentários em nota de rodapé na introdução, quanto ao acréscimo de 4 casos na amostra, relacionados à atualização de dados nos sistemas da PCDF e MPDFT, após a conclusão das investigações, entre os momentos de início e conclusão da pesquisa.
} 
de feminicídios (DISTRITO FEDERAL, 2017). Estas diretrizes e protocolos buscam incluir as "lentes de gênero" no trabalho de investigação criminal e processamento judicial.

Assim, o paradigma de gênero torna-se uma ferramenta analítica para a investigação criminal, que deve produzir prova do histórico de violência entre as partes, especialmente os atos de poder, controle coercitivo e disciplina sobre a vítima, bem como das dificuldades para a mulher romper o ciclo de violência, de forma a facilitar o reconhecimento de que a morte foi manifestação da violência de gênero derivada da estrutura social sexista (ÁVILA, 2018).

A perspectiva de gênero deve abrir novas linhas investigativas aos peritos quanto à cena do crime e à autópsia. Por exemplo, sinais de objetos quebrados na casa podem sinalizar um histórico de violências anteriores; informações em dispositivos de informática podem sinalizar stalking e controle coercitivo. Quanto à análise do corpo da vítima, cumpre ter especial atenção com sinais de violência sexual anterior ou posterior ao crime, e ainda os sinais de violência brutal em áreas erógenas, indicativas do crime de ódio. Abrem-se as portas para novos aportes de perícias psicossociais para esclarecerem aspectos sociais ou psicológicos do histórico da violência e seus fatores de risco, colaborando para se traduzir aos jurados aspectos invisíveis desta violência estrutural (v. ONU MULHERES; BRASIL, 2016; ÁVILA, 2016).

Especialmente em casos de tentativa de feminicídio, quando há uma sobrevivente, é essencial aplicar as disposições da Lei Maria da Penha no âmbito do Tribunal do Júri, concedendose as medidas protetivas de urgência e assegurando-se a integração da vítima com a rede de serviços de proteção. Há uma preocupação especial em manter o agressor preso durante o processo se houver um risco imediato à segurança da vítima. As interações da vítima e seus familiares com o sistema de justiça devem ser humanizadas, com respeito e dignidade, evitando-se a denominada "revitimização" e buscando fomentar a sua colaboração com o processo e a percepção de justiça e reparação (ONU MULHERES; BRASIL, 2016). A integração com os serviços de monitoramento das medidas protetivas, em muitos Estados denominados de "Patrulhas Maria da Penha" (no DF o PROVID), e o uso de aplicativos de contato celular para emergências (no DF o programa Viva Flor) são igualmente estratégias relevantes para evitar o assédio persecutório e o risco de novos ataques (FBSP, 2019). Igualmente, o sistema de justiça deve-se abrir-se às redes de atendimento psicossocial às mulheres, a fim de superar uma percepção disfuncnional da complexidade da violência de gênero (TAVARES; SILVA, 2017).

Outra diretriz contra a revitimização é o chamado direito à verdade e o direito à preservação da memória da vítima. Há um direito às vítimas sobreviventes ou a seus familiares de verem identificado o agressor, esclarecidas suas motivações e, em casos de feminicídio consumado, recuperarem o corpo da vítima. Esse direito abrange o direito à informação, devendo as instituições de persecução penal terem a iniciativa de proporcionar aos familiares informações relevantes e 
acessíveis sobre o desenvolvimento do processo, evitando-se a exposição desnecessária da privacidade da vítima (ONU MULHERES; BRASIL, 2016).

Pesquisas tem documentado julgamentos morais da vítima durante os julgamentos, usualmente ligados à sua culpabilização por ter provocado o crime, por não ser uma boa mãe, por ter usado roupas provocadoras em público ou por ter ofendido a autoridade do companheiro (MACHADO, 2015; PIRES, 2018). O direito à memória da vítima compreende um procedimento respeitoso, que tenha garantias contra a reprodução destes estereótipos de gênero. Não se deve expor desnecessariamente a privacidade da mulher no julgamento, como, por exemplo, explorar temas de fundo sexista para desacreditar seu caráter. Ao contrário, a investigação deve por acento nos fatores de risco à luz das relações de gênero. Esta perspectiva cria um papel renovado do Ministério Público enquanto garantidor dos direitos das vítimas (ONU MULHERES; BRASIL, 2016).

A Recomendação Geral n. 33/2015 do Comitê sobre a Eliminação da Discriminação contra as Mulheres das Nações Unidas, que trata do acesso das mulheres à justiça, dispõe sobre os estereótipos e preconceitos de gênero no sistema de justiça. Consta da Recomendação (ONU, 2015, item 26):

26. Os estereótipos e os preconceitos de gênero no sistema judicial têm consequências de amplo alcance para o pleno desfrute pelas mulheres de seus direitos humanos. Eles impedem o acesso das mulheres à justiça em todas as áreas do direito, e podem ter um impacto particularmente negativo sobre as mulheres vítimas e sobreviventes da violência. Os estereótipos distorcem percepções e resultam em decisões baseadas em crenças e mitos preconcebidos em vez de fatos relevantes. Com frequência, juízes adotam rígidos estândares sobre comportamentos que consideram apropriados para as mulheres, penalizando aquelas que não agem conforme esses estereótipos. Os estereótipos também afetam a credibilidade dada às vozes, aos argumentos e depoimentos das mulheres, sistema de justiça, que pode, por como partes e testemunhas. Esses estereótipos podem levar juízes a mal interpretarem ou aplicarem as leis. Isso tem profundas consequências, por exemplo, no direito penal, quando resulta que perpetradores de violações a direitos das mulheres não sejam considerados juridicamente responsáveis, mantendo-se assim uma cultura de impunidade. Em todas as áreas do direito, os estereótipos comprometem a imparcialidade e integridade do sistema de justiça, que podem, por sua vez, levar à denegação da justiça, incluindo a revitimização de denunciantes.

Esta Recomendação deriva da Convenção sobre a Eliminação de Todas as Formas de Discriminação Contra as Mulheres (CEDAW), tratado internacional aprovado pela Assembleia Geral das Nações Unidas em 1979 e ratificado pelo Brasil (Decreto n. 4.377/2002), o qual possui estatura de norma jusfundamental (cf. CF/1988, art. $5^{\circ}, \S 2^{\circ}$ ). Assim, a Recomendação integra necessariamente sua interpretação sistemática, nos termos do art. 31.3 da Convenção de Viena (Decreto n. 7.030/2009). Portanto, há uma norma jurídica em vigor no Brasil que proíbe o uso de expressões e argumentos potencialmente discriminatórios às mulheres nos julgamentos de feminicídios e de todas as formas de violência contra as mulheres. 
Finalmente, deve-se proporcionar justa e devida reparação pela violência sofrida, em favor da vítima sobrevivente, de seus familiares ou de pessoa que convivia com ela, como vítimas secundárias. No já referido caso da CIDH $(2009, \S 450)$, decidiu-se que o conceito de reparação integral, em um contexto de discriminação estrutural às mulheres, "deve[m] ter uma vocação transformadora desta situação, de tal forma que as mesmas tenham um efeito não somente restitutivo, mas também corretivo". No Brasil, o juiz, ao proferir sentença condenatória, "fixará valor mínimo para reparação dos danos causados pela infração, considerando os prejuízos sofridos pelo ofendido" (CPP, art. 387, inciso IV). Acórdão do STJ fixou a tese com repercussão geral de que "Nos casos de violência contra a mulher praticados no âmbito doméstico e familiar, é possível a fixação de valor mínimo indenizatório a título de dano moral, desde que haja pedido expresso da acusação ou da parte ofendida, ainda que não especificada a quantia, e independentemente de instrução probatória” (BRASIL, 2018). Este acórdão entendeu que os danos morais decorrentes da VDFCM são propter rem, ou seja, derivam do próprio ato ilícito, pois "uma vez demonstrada a agressão à mulher, os danos psíquicos dela derivados são evidentes e nem têm mesmo como ser demonstrados".

Um importante avanço na incorporação da diretriz de responsabilização dos autores de feminicídio foi decisão pioneira do Tribunal de Justiça do Distrito Federal e Territórios (TJDFT), reconhecendo que a qualificadora do feminicídio possui natureza objetiva, ou seja, não deriva de uma motivação do agente, mas de um contexto objetivo de violência estrutural (DISTRITO FEDERAL, 2015), o que é importante para evitar que eventual reconhecimento de privilégio subjetivo (como a suposta provocação pela vítima) viesse afastar a possibilidade de se reconhecer o feminicídio (MACHADO, 2019). Todavia, esta perspectiva estrutural das relações de gênero desiguais não se nota em parte da jurisprudência afeta aos casos de VDFCM, que exigem que o juiz perscrute se haveria alguma "motivação de gênero" no caso concreto, além da evidente desvantagem que todas as mulheres estão ao sofrerem violência nestes contextos situacionais, o que tem levado muitos magistrados a recusarem proteção às mulheres ante a invisibilidade do caráter estrutural das relações de gênero (v. MACHADO, 2016; PIRES, 2018; TÁVORA; ÁVILA, 2019).

Segundo Pires (2018), estas diretrizes de efetividade quanto à persecução penal do feminicídio têm sido importantes para a capacitação dos profissionais do sistema de justiça criminal, aproximando-os da perspectiva de gênero. Todavia, este autor relembra que há pontos de resistência, relacionados ao uso de estereótipos de gênero, à persistência de teses defensivas culpabilizadoras das vítimas, aos limites éticos do exercício da garantia da plenitude de defesa, à descontextualização da estruturalidade da violência de gênero, ao silenciamento quanto a marcadores sociais interseccionais e à ausência de enfoque de gênero e fixação da reparação de danos nas sentenças condenatórias. 
Vejamos o resultado da pesquisa documental dos feminicídios no DF.

\section{Análise do fluxo processual dos casos de feminicídio no DF}

Dentre os 34 casos de feminicídio consumado em contexto de VDFCM ocorridos no DF durante os anos de 2016 e 2017, em 41,2\% dos casos ( $n=14$ ) houve prisão em flagrante. Dentre os casos em que houve prisão em flagrante, ela foi convertida em prisão preventiva na audiência de custódia em 92,9\% dos casos $(n=13)$. Usualmente, após o ajuizamento da denúncia há o requerimento e deferimento de prisão preventiva; dentre os processos que chegaram a julgamento plenário ( $n=23)$, em 91,3\% ( $n=21$ ) o réu estava em prisão preventiva no momento do julgamento.

Houve oferecimento de denúncia em $85,3 \%$ dos casos $(n=29)$. Em relação aos casos arquivados $(\mathrm{n}=5,14,7 \%)$, o motivo foi a morte do agressor, pois tratava-se de feminicídio seguido de suicídio. Dentre o universo mais amplo constante do levantamento preliminar ( $n=44)$, em apenas dois casos não houve o esclarecimento da autoria ${ }^{11}$.

Dentre os casos denunciados, $86,2 \%$ deles $(n=25)$ havia sido pronunciado. Dentre os casos não pronunciados $(n=4)$, a causa mais comum $(n=3,10,3 \%)$ foi de processo suspenso após o réu não ser localizado para citação pessoal, ocorrendo sua citação por edital (CPP, art. 366). Em um caso, o processo aguardava a localização de testemunhas de acusação. Não houve nenhum caso de decisão de impronúncia ou absolvição sumária, diferentemente de pesquisa anterior, que documentou percentual de $17 \%(n=2)$ de impronúncia e $8 \%(n=1)$ de absolvição sumária (DINIZ, 2015)

Dentre os casos pronunciados, $92 \%$ deles $(n=23)$ já haviam sido julgados pelo plenário do júri. Dentre os casos julgados, em todos os casos, exceto um, houve condenação ( $n=22,95,6 \%$ ). No único caso sem condenação, houve a absolvição imprópria, com aplicação de medida de segurança pelo prazo mínimo de 3 anos, pois constava dos autos laudo do IML documentando a inimputabilidade do réu, que praticou o feminicídio contra sua genitora e esganadura com resultado de lesões graves contra sua avó. Dentre os casos julgados, em 69,6\% (n=16) houve o trânsito em julgado no momento da conclusão da pesquisa (março de 2020). Este percentual de elevadas condenações segue tendência identificada em pesquisa anterior, relativa aos homicídios de mulheres em contexto de VDFCM de 2006-2011 (DINIZ, 2015), que documentou que, dentre os casos julgados pelo plenário do júri, em 97\% (n=57) houve condenação, em 2\% (n=1) desclassificação, e em $2 \%$ (n=1) absolvição.

\footnotetext{
${ }^{11}$ Ver nota de rodapé na introdução.
} 
Tabela1: Quadro resumo das informações processuais

\begin{tabular}{rcrcc}
$\begin{array}{c}\text { Fase } \\
\text { processual }\end{array}$ & $\begin{array}{c}\text { De } \\
\text { núncia }\end{array}$ & $\begin{array}{r}\text { Pr } \\
\text { onúncia }\end{array}$ & $\begin{array}{c}\text { PI } \\
\text { enário }\end{array}$ & $\begin{array}{c}\text { Trânsito em } \\
\text { julgado }\end{array}$ \\
\hline Sim & $\begin{array}{r}29 \\
(85,3 \%)\end{array}$ & $\begin{array}{r}25 \\
(86,2 \%)\end{array}$ & $\begin{array}{r}23 \\
(92 \%)\end{array}$ & $16(69,6 \%)$ \\
Não & $\begin{array}{r}5 \\
(14,7 \%)\end{array}$ & $\begin{array}{r}4 \\
(13,8 \%)\end{array}$ & $\begin{array}{c}(8 \%) \\
2\end{array}$ & $7(30,4 \%)$ \\
\hline Total & $\begin{array}{r}34 \\
(100 \%)\end{array}$ & $\begin{array}{r}29 \\
(100 \%)\end{array}$ & $\begin{array}{c}25 \\
(100 \%)\end{array}$ & $23(100 \%)$ \\
\hline
\end{tabular}

As Tabelas 2-4 indicam o tempo de tramitação processual do fato até a denúncia (média de 125 dias, mediana de 35 dias), do fato à pronúncia (média de 357 dias, mediana de 252 dias), e do fato ao julgamento plenário (média de 713 dias, mediana de 553 dias) ${ }^{12}$. Em relação à pena aplicada, tanto a média quanto a mediana foram de 20 anos (Tabela 5). Neste ponto, verifica-se uma elevação tanto do tempo de tramitação quanto da pena média em relação à pesquisa anterior (DINIZ, 2015), em que o tempo médio do fato à denúncia foi de 119 dias e da denúncia ao julgamento plenário foi de 449 dias, bem como em que a pena média dos homicídios de mulheres em contexto de VDFCM foi de 15 anos. Este achado confirma a hipótese de Pires (2018) de que a criminalização do feminicídio ensejou um aumento da punitividade em termos quantitativos de pena.

Tabela 2: Informações da variável Tempo do fato até a denúncia (em dias)

\begin{tabular}{cc}
\hline Informação & Valor \\
\hline Média & 125,1 \\
Desvio Padrão & 240,2 \\
Máximo & 970 \\
Q3 & 74 \\
Mediana & 35 \\
Q1 & 18 \\
Mínimo & 9 \\
\hline
\end{tabular}

Tabela 3: Informações da variável Tempo do fato até a pronúncia (em dias)

\begin{tabular}{cc}
\hline Informação & Valor \\
\hline Média & 357,2 \\
\hline Desvio Padrão & 276,5 \\
Máximo & 1.257 \\
Q3 & 402 \\
Mediana & 252 \\
Q1 & 215 \\
\hline Mínimo & 118 \\
\hline
\end{tabular}

\footnotetext{
${ }^{12}$ As Tabelas apresentam os dados de levantamento das estatísticas ordinais. Nestes casos, Q3 representa o terceiro quartil, ou seja, o valor que divide o universo de dados em $75 \%$ das observações abaixo dele e $25 \%$ acima. No Q1 (primeiro quartil), $25 \%$ estão abaixo e 75\% das observações estão acima daquele valor. A mediana é o valor que divide em 50\% das observações acima e 50\% abaixo.
} 
Tabela 4: Informações da variável Tempo do fato até o julgamento em plenário (em dias).

\begin{tabular}{cc}
\hline Informação & Valor \\
\hline Média & 712,9 \\
Desvio Padrão & 428,3 \\
Máximo & 2.190 \\
Q3 & 921 \\
Mediana & 553 \\
Q1 & 445,5 \\
Mínimo & 268 \\
\hline
\end{tabular}

Tabela 5: Informações da variável Pena aplicada (em anos).

\begin{tabular}{cc}
\hline Informação & Valor \\
\hline Média & 20,01 \\
Desvio Padrão & 5,64 \\
Máximo & 31,3 \\
Q3 & 22,9 \\
Mediana & 20 \\
Q1 & 16,95 \\
\hline Mínimo & 6 \\
\hline
\end{tabular}

Em todos os casos denunciados, o Ministério Público incluiu a qualificadora do feminicídio na denúncia, bem como houve concurso de outras qualificadoras. Analisando-se a evolução das qualificadoras da denúncia para a pronúncia, em dois casos houve a exclusão de uma qualificadora (um caso a qualificadora de recurso que dificultou ou tornou impossível a defesa da vítima e outro caso a qualificadora de motivo fútil). Em um caso a pronúncia incluiu uma qualificadora não prevista expressamente na tipificação da denúncia (dissimulação), por considerar que ela estava implicitamente descrita na narrativa.

Em relação ao julgamento do plenário do júri com condenação (n=22), em um caso excluiuse a qualificadora do feminicídio e em outro caso houve a retirada da qualificadora de recurso que dificultou ou tornou impossível a defesa do ofendido. Verifica-se uma alteração de padrão em relação à pesquisa anterior à criminalização do feminicídio (DINIZ, 2015), que documentou que em apenas $28 \%$ dos casos houve o reconhecimento da agravante da violência doméstica, incluída no art. 61, inciso II, alínea “f”, do Código Penal pela Lei Maria da Penha. Outra pesquisa nacional documentou fenômeno semelhante de baixa referência à Lei Maria da Penha nos julgamentos de mortes de mulheres em contexto de VDFCM (MACHADO, 2015). Agora, como esta circunstância configura uma qualificadora e já consta da denúncia do Ministério Público, favoreceu-se o reconhecimento do contexto de VDFCM nos julgamentos.

Neste único caso de exclusão da qualificadora do feminicídio, tratava-se de réu policial militar que praticou o crime contra a ex-namorada, quando a encontrou em via pública com novo namorado. Este também foi o caso com a menor das penas aplicadas, com condenação à pena mínima pelo homicídio simples, de 6 anos de reclusão, além de ser um dos dois únicos processos 
em que o réu respondeu em liberdade. O Ministério Público havia inicialmente denunciado o caso com as qualificadoras do feminicídio e motivo fútil, mas na fase da pronúncia o próprio Ministério Público solicitou a exclusão da qualificadora do motivo fútil, o que foi acatado pelo magistrado ao argumento de que o sistema acusatório não permitiria ao juiz incluir a qualificadora contra a manifestação do Ministério Público.

Dentre os processos julgados com condenação $(n=22)$, em $13,6 \%(n=3)$ houve a aplicação da causa de aumento de pena de o crime ter sido praticado na presença de descendente da vítima (CP, art. $121, \S 7^{\circ}$, inciso III). Informação sobre este contexto estava também presente em um dos processos sem denúncia, dois processos dentre os denunciados e não julgados, bem como no processo com absolvição sumária, perfazendo o total de $20,5 \%$ do total dos feminicídios praticados na presença dos descendentes da vítima $(\mathrm{n}=7)$.

Ver comparação das qualificadoras nas fases de denúncia, pronúncia e julgamento plenário do júri (Tabela 6), e as combinações de qualificadoras mais usuais nas denúncias do Ministério Público (Tabela 7) ${ }^{13}$ :

Tabela 6: Distribuição de frequência de opções selecionadas que se aplicam a outras qualificadoras individuais

\begin{tabular}{|c|c|c|c|}
\hline Qualificadora & Denúncia & Pronúncia & Julgamento \\
\hline I - mediante motivo torpe & $14(48,3 \%)$ & $12(48 \%)$ & $11(50 \%)$ \\
\hline II - por motivo fútil & $7(24,1 \%)$ & $4(16 \%)$ & $3(13,6 \%)$ \\
\hline III - com emprego de asfixia & $3(10,3 \%)$ & $3(12 \%)$ & $3(13,6 \%)$ \\
\hline III - com emprego de meio cruel & $7(24,1 \%)$ & $6(24 \%)$ & $5(22,7 \%)$ \\
\hline $\begin{array}{l}\text { IV - mediante outro recurso que dificulte ou } \\
\text { torne impossível a defesa do ofendido }\end{array}$ & $21(72,4 \%)$ & $17(68 \%)$ & $14(63,6 \%)$ \\
\hline IV - mediante dissimulação & - & $1(4 \%)$ & $1(4,5 \%)$ \\
\hline V- para assegurar a impunidade de outro crime & $1(3,4 \%)$ & $1(4 \%)$ & - \\
\hline $\begin{array}{l}\text { VI - contra a mulher por razões de condição de } \\
\text { sexo feminino. c/c } \S 2^{\circ}-\mathrm{A}\end{array}$ & $29(100 \%)$ & $25(100 \%)$ & $22(100 \%)$ \\
\hline Quantidade de casos & 29 & 25 & 22 \\
\hline
\end{tabular}

\footnotetext{
${ }^{13} \mathrm{Na}$ metodologia da contagem, considerou-se como "pronúncia" a decisão final sobre a pronúncia, confirmada em eventual recurso ao TJDFT. Em apenas um caso houve a exclusão da qualificadora a requerimento do Ministério Público.
} 
]Tabela 7: Distribuição de frequência de opções selecionadas que se aplicam a combinações de qualificadoras nas denúncias do MP

\section{Qualificadora}

Quantidade de

casos

I - mediante motivo torpe, IV - mediante outro recurso que dificulte ou torne impossível a defesa do ofendido, VI - contra a mulher por razões de condição de sexo feminino c/c $\S 2^{\circ}-\mathrm{A}$

IV - mediante outro recurso que dificulte ou torne impossível a defesa do ofendido, VI - contra a mulher por razões de condição de sexo feminino. c/c $\S 2^{\circ}$ -

A

I - mediante motivo torpe, VI - contra a mulher por razões de condição de sexo feminino. $\mathrm{c} / \mathrm{c} \S 2^{\circ}-\mathrm{A}$

II - por motivo fútil, III - com emprego de meio cruel, IV - mediante outro recurso que dificulte ou torne impossível a defesa do ofendido, VI - contra a mulher por razões de condição de sexo feminino. c/c $\S 2^{\circ}-\mathrm{A}$

I - mediante motivo torpe, III - com emprego de meio cruel, IV - mediante outro recurso que dificulte ou torne impossível a defesa do ofendido, VI - contra a mulher por razões de condição de sexo feminino. c/c $\S 2^{\circ}$-A

II - por motivo fútil, IV - mediante outro recurso que dificulte ou torne impossível a defesa do ofendido, VI - contra a mulher por razões de condição de sexo feminino. c/c $\S 2^{\circ}$-A

III - com emprego de asfixia, VI - contra a mulher por razões de condição de sexo feminino. c/c $\S 2^{\circ}$-A

I - mediante motivo torpe, III - com emprego de asfixia, IV - mediante outro recurso que dificulte ou torne impossível a defesa do ofendido, VI - contra a mulher por razões de condição de sexo feminino. c/c $\S 2^{\circ}-\mathrm{A}$

I - mediante motivo torpe, IV - mediante outro recurso que dificulte ou torne impossível a defesa do ofendido, V- para assegurar a impunidade de outro crime, VI - contra a mulher por razões de condição de sexo feminino c/c $\S 2^{\circ}-\mathrm{A}$

II - por motivo fútil, III - com emprego de meio cruel, VI - contra a mulher por razões de condição de sexo feminino. c/c $\S 2^{\circ}$-A

II - por motivo fútil, VI - contra a mulher por razões de condição de sexo feminino. $\mathrm{c} / \mathrm{c} \S 2^{\circ}-\mathrm{A}$

III - com emprego de meio cruel, IV - mediante outro recurso que dificulte ou torne impossível a defesa do ofendido, VI - contra a mulher por razões de condição de sexo feminino. c/c $\S 2^{\circ}$-A

VI - contra a mulher por razões de condição de sexo feminino. c/c $\S 2^{\circ}$-A 
Se o resultado é positivo no aspecto de produção de condenações, no campo da reparação à vítima aparentemente é insuficiente. Dos casos com ajuizamento de denúncia $(n=29)$, em apenas 24,1\% casos $(n=7)$ o Ministério Público formulou requerimento da denúncia de fixação de indenização em favor dos familiares da vítima, o que seria essencial para apreciação judicial (BRASIL, 2018). Dentre os processos em que houve condenação ( $n=22)$, em nenhum caso houve fixação de indenização em favor dos familiares da vítima. Dentre os casos em que o Ministério Público formulou o requerimento na denúncia e houve condenação $(n=6)$, em dois casos o juiz denegou por "falta de elementos", dois por falta de requerimento pela parte interessada, um por falta de individualização dos herdeiros que viriam a receber a indenização, e em um caso não houve nenhuma menção na sentença ao pedido ministerial de indenização. Dentre os demais casos de condenação $(n=16)$, em 7 casos o magistrado informou que deixava de fixar a indenização por falta de pedido da parte do Ministério Público, e em outros 9 casos simplesmente não se discutiu o tema na sentença.

Estes achados indicam que não há uma prática padronizada no MPDFT de se formular requerimento na denúncia de indenização em favor da vítima e, mesmo quando o pedido é eventualmente formulado, ele não é usualmente aceito pelo Judiciário. Esta situação pode ainda indicar um possível receio pela acusação de introduzir discussões patrimoniais no julgamento do feminicídio em Plenário do Júri, para se evitar a fuga do tema central quanto à condenação criminal.

\section{Reflexões para o aperfeiçoamento da persecução penal}

\subsection{A investigação criminal como instrumento de fomento às políticas de prevenção da violência} de gênero

Para além de serem instrumento de promoção da responsabilização de agressores, os inquéritos policiais sobre os feminicídios são o locus de esclarecimento pelo Estado de todas as circunstâncias das mortes das mulheres, o que subsidia a posterior construção de políticas públicas de prevenção. Essa perspectiva exigiria que a investigação criminal fosse além do mero esclarecimento da autoria e materialidade, mas incorporasse informações sobre o histórico relacional dos conflitos que levaram ao feminicídio.

Por exemplo, nos casos de feminicídio seguido de suicídio $(n=5)$, houve o encerramento sumário das investigações. A leitura do inquérito policial usualmente não permitiu compreender por que o agressor praticou o feminicídio e o que poderia ter sido feito para evitar aquela morte. Para estas situações, seria importante que o Ministério Público fomentasse a continuidade das investigações para o pleno esclarecimento das circunstâncias da morte, e dos fatores de risco presentes, a fim de subsidiar posteriores políticas públicas de prevenção. 
Outra informação importante para a prevenção dos feminicídios é a compreensão da intersecção de marcadores esrtruturais de gênero, raça e classe, dentre outros (ONU MULHERES; BRASIL, 2016; MACHADO, 2019). Todavia, em 29\% dos casos não havia informação nos autos do feminicídio sobre a raça/cor dos agressores, sendo que a informação da vítima consta usualmente dos laudos cadavéricos ou da declaração de óbito. Portanto, seria relevante que houvesse preenchimento sistemático do campo raça/cor no prontuário de identificação civil da PCDF ou no boletim de ocorrência.

Ademais, nem sempre a informação relativa à raça/cor da vítima foi fidedigna. Por exemplo, no caso de Cecília, no laudo do IML consta que a vítima tinha cor branca, mas na declaração de óbito e no prontuário civil consta cor parda. A mãe da vítima informa que era branca, mas a análise das fotos do cadáver, constantes dos autos, indicava que a vítima era parda. No total, em 7 casos não constou do registro do IML a informação sobre a raça/cor da vítima e em 12 casos houve divergência da informação raça/cor entre os dados da declaração de óbito e o laudo cadavérico do IML. Em 5 casos na declaração constou parda e no laudo do IML constou branca, em 4 casos na declaração constou branca e no laudo do IML constou parda, em 2 casos na declaração constou preta e no laudo do IML constou parda, e em um caso na declaração constou parda e no laudo do IML constou preta. Convém haver maior acuidade nessas informações.

\subsection{Investigação criminal com perspectiva de gênero}

Um dos pontos mais relevantes para o aperfeiçoamento da investigação criminal de casos de feminicídio é a incorporação da perspectiva de gênero (BRASIL et al., 2016; ONU MULHERES; BRASIL, 2016). Isso significa compreender como as complexidades das relações de gênero fomentam mortes de mulheres, tanto no espaço privado quanto no público. Portanto, explicitar essas relações de poder, o histórico de controle sobre a vítima e os sinais de dominação masculina e subordinação feminina presentes na cena do crime, é relevante para compreender não apenas a motivação do crime, como as razões estruturais de gênero incidentes no caso, tudo a facilitar a capitulação do crime como feminicídio e, portanto, proporcionar adequada responsabilização do agressor.

Como mencionado, MPDFT e PCDF possuem diretrizes de atuação nos casos de feminicídios (ÁVILA, 2016; DISTRITO FEDERAL, 2017). Todavia, em diversos casos analisados, verificou-se que poderia haver um aperfeiçoamento da investigação criminal. Em todos os 34 casos houve coleta de material para exames de investigação do óbito da vítima, mas em apenas 10 casos $(29,4 \%)$ houve juntada aos autos dos resultados dos exames. 
Os exames solicitados foram os seguintes:

Tabela 8: Exames solicitados nas vítimas de feminicídio

\begin{tabular}{|l|c|}
\hline \multicolumn{1}{|c|}{ RESULTADO DOS EXAMES } & TOTAL DE CASOS \\
\hline SANGUE EM FTA & 32 \\
\hline SANGUE PARA TOXICOLOGICO & 23 \\
\hline SANGUE PARA ALCOOLEMIA & 21 \\
\hline URINA PARA ALCOOLEMIA & 11 \\
\hline URINA PARA TOXICOLOGICO & 11 \\
\hline SWAB ANAL & 08 \\
\hline SWAB VAGINAL & 08 \\
\hline SWAB SUBUNGUEAL & 08 \\
\hline HUMOR VÍTREO PARA ALCOOLEMIA & 06 \\
\hline HUMOR VÍTEREO PARA & 06 \\
TOXICOLOGICO & 01 \\
\hline SANGUE DO FETO PARA DNA & 01 \\
\hline SWAB DE CAVIDADE ORAL & 01 \\
\hline FRAGMENTO DE VISCERA - ESTOMAGO & $\mathbf{1 3 7}$ \\
\hline TOTAL DE EXAMES NOS 34 CASOS & \\
\hline
\end{tabular}

Dentre os 10 casos que tiveram os resultados juntados aos autos, os resultados dos exames foram:

Tabela 9: Resultados de exames obtidos nas vítimas de feminicídio

\begin{tabular}{|l|c|c|c|}
\hline \multicolumn{1}{|c|}{$\begin{array}{c}\text { TIPOS DE EXAMES / } \\
\text { RESULTADOS }\end{array}$} & INCONCLUSIVO & POSITIVO & NEGATIVO \\
\hline TOXICOLOGICO & & 04 & 01 \\
\hline ALCOOLEMIA & 01 & 02 & 03 \\
\hline PESQUISA DE DNA & & 02 & 02 \\
\hline PESQUISA DE ESPERMATOZÓIDES & 01 & 10 & 08 \\
\hline TOTAIS PARCIAIS & \multicolumn{3}{|c|}{} \\
\hline TOTAL GERAL & $\mathbf{1 9}$ & \\
\hline
\end{tabular}


Especificamente em relação aos exames das vítimas solicitados e não juntados aos autos, a tabela 10 indica os tipos de exames.

Tabela 10: Número de casos com exames nas vítimas de feminicídio solicitados e "não juntados" aos autos.

\begin{tabular}{|l|c|}
\hline TIPOS DE EXAMES & $\begin{array}{c}\text { TOTAL } \\
\text { (24 casos) }\end{array}$ \\
\hline PESQUISA DE DNA EM SANGUE & 21 \\
\hline TOXICOLOGICO (SANGUE, URINA OU HUMOR VÍTREO) & 17 \\
\hline ALCOOLEMIA (SANGUE, URINA OU HUMOR VÍTREO) & 15 \\
\hline PESQUISA DE DNA EM TECIDOS & 5 \\
\hline SEM COLETA POR INTERNAÇÃO PERI ÓBITO & 5 \\
\hline PESQUISA DE ESPERMATOZÓIDES & 4 \\
\hline SEM REGISTRO DE COLETA & 2 \\
\hline TOTAL DE EXAMES & $\mathbf{6 9}$ \\
\hline
\end{tabular}

Estes achados indicam a relevância de os Promotores de Justiça do Júri zelarem pela juntada dos laudos solicitados ao IML, antes do julgamento do caso.

Em outros casos, verificou-se necessidade de aperfeiçoamento dos resultados dos laudos. Por exemplo, no caso de Lívia, ela foi encontrada morta na cama, apenas de calcinha, que estava deslocada para a lateral, deixando exposta a região pubiana. Todavia, o IML não realizou a coleta de material vaginal e anal para pesquisa de espermatozoides para investigação sobre possível violência sexual associada à morte. Já no caso de Cecília, houve coleta de material vaginal da vítima, mas não houve a juntada do resultado aos autos antes do julgamento.

No caso de Letícia, o IML coletou no exame cadavérico da vítima amostras para análise de toxicologia e de alcoolemia, mas os resultados não foram juntados aos autos. Não ficou claro nos autos o motivo da não juntada, o que levanta a hipótese de possível receio de prejudicar a imagem da vítima perante o júri. No caso de Joaquina, não houve perícia de local, pelo fato de o crime ter sido praticado em via pública, de chão batido, e ter chovido na sequência, sendo entregue na Delegacia de Polícia uma sacola com as roupas da vítima. Apesar de haver notícias de luta antes do feminicídio e histórico de violências anteriores, não houve perícia nos objetos quebrados no interior da residência em relação às violências anteriores, nem no hospital onde a vítima recebeu atendimento médico em razão das queimaduras decorrentes do feminicídio. 
Além da violência no momento do feminicídio, é conveniente que a investigação criminal se aprofunde quanto ao histórico de violências anteriores entre o casal, especialmente durante as entrevistas com familiares, vizinhos e amigas da vítima. Uma estratégia é sempre juntar ao processo os boletins de ocorrência de casos anteriores de violência doméstica pelo agressor. Por exemplo, no caso de Maria, o agressor tinha dois outros processos de violência doméstica contra ela, cujos boletins de ocorrência não foram juntados aos autos. No caso de Mariana, o agressor tinha condenação anterior por violência doméstica contra a cunhada, mas não houve juntada aos autos da sentença condenatória deste processo anterior, que poderia trazer informações relevantes sobre os antecedentes do agressor. Outra estratégia pode ser ouvir vítimas anteriores do mesmo agressor. Por exemplo, no caso de Nádia, havia registros anteriores de VDFCM contra a ex-companheira e esta não foi ouvida no processo.

Mesmo que não haja histórico de registros policiais anteriores de violência doméstica, é importante entrevistar os familiares da vítima. No caso de Gabriela, por exemplo, nenhum familiar da vítima foi ouvido durante a investigação, de forma que a história da vítima não foi resgatada na narrativa processual. No caso de Maria, a entrevista realizada pela pesquisa com sua irmã trouxe informações relevantes sobre as violências anteriores, que não constavam dos autos do processo. Já no caso de Manuela, a irmã da vítima, com quem ela residia recentemente, não foi ouvida na fase investigativa. Havia um histórico de vários atos de violência doméstica contra a vítima, mas estas informações apenas foram trazidas ao processo quando esta irmã da vítima se habilitou como assistente da acusação durante o julgamento. Se ela não houvesse tido a iniciativa de colaborar com o processo, informações relevantes ao julgamento seriam perdidas. A pesquisa documentou que as informações mais importantes que foram fornecidas por familiares das vítimas e não constavam dos autos dos processos foram as relacionadas a: isolamento social da vítima (60\%), histórico de a vítima ter sofrido violências sexuais anteriormente pelo agressor $(33,3 \%)$, agravamento do histórico de violências antes do feminicídio (27,3\%), histórico de o agressor quebrar objetos da vítima (27,3\%), vítima estar grávida ou ter dado a luz nos últimos 18 meses (25\%), vítima ser dependente financeira do agressor (25\%), o agressor ficar mais violento quando está sob efeito de álcool ou outras drogas $(20 \%)^{14}$. Estas informações podem ser úteis tanto ao julgamento do feminicídio, quanto à produção de informações para subsidiar posteriores políticas públicas de prevenção. Portanto, a polícia deveria sempre fazer contato com os parentes da vítima durante a investigação e

\footnotetext{
${ }^{14}$ A pesquisa levantou essas informações nos processos judiciais e em entrevistas a familiares. Os percentuais referem-se à proporção em que a informação apenas foi obtida na entrevista com os familiares, em comparação aos casos em que as informações já constavam dos autos. Ou seja, em mais da metade dos casos em que se obteve a informação de que a vítima estava em situação de isolamento social, esta informação não constava dos autos dos processos de feminicídio, apenas foi obtida na entrevista com familiares.
} 
o Ministério Público deveria sempre diligenciar o contato com os familiares da vítima para acompanharem o julgamento, se possível arrolando-os como testemunhas para ao plenário.

É também conveniente a realização de estudos psicossociais post mortem pelo setor psicossocial (SETPS) do MPDFT, ou sua "autópsia psicológica" (ONU MULHERES; BRASIL, 2016, p. 79; v. ainda: ÁVILA, 2016, p. 8). A pesquisa indicou que em apenas dois casos houve realização desse estudo (Melissa e Rafaela), sendo que nestes casos o estudo aportou informações relevantes sobre o histórico da violência, contribuindo para a contextualização do feminicídio, para além da perspectiva protetiva na abordagem dos familiares. Por exemplo, no caso de Melissa, o estudo trouxe informações sobre o contexto familiar do caso e permitiu localizar outros familiares não identificados na investigação policial, que foram posteriormente arrolados para testemunhar no julgamento plenário do júri. Em ambos os casos a condenação em plenário ocorreu conforme o pedido feito pelo Ministério Público, sendo possível afirmar que o estudo psicossocial contribuiu para este resultado.

Também convém investigar, caso a vítima tenha registrado ocorrências policiais anteriormente, se ela já realizou outros atendimentos psicossociais. No caso de Vanessa, ela havia realizado um acolhimento no setor psicossocial do MPDFT, em processo anterior de VDFCM, com diversas informações sobre o histórico de violência, mas o respectivo relatório não foi juntado ao processo do júri.

Outra estratégia pode ser a investigação dos prontuários médicos da vítima na rede pública. Verificou-se que em diversos casos a vítima estava sofrendo violência doméstica, recebeu prévio atendimento na rede pública de saúde, mas estas informações não foram trazidas aos autos. Por exemplo, em um dos casos, a vítima estava sofrendo múltiplas violências do agressor, com vários atendimentos na rede de saúde com ideação suicida, informação que não foi trazida aos autos. Também no caso de Zélia constava outro episódio de agressão física nos prontuários dela e de seu companheiro, alguns anos antes do feminicídio.

Ademais, é importante que a investigação criminal incorpore estratégias de proteção aos familiares da vítima, especialmente que se esclareça se os familiares estão com medo do agressor e se ofereça a possiblidade de acompanhamento pelo PROVID da PMDF. A pesquisa indicou que, dentre os 19 familiares das vítimas entrevistados, em 2 casos eles ainda estavam com medo do agressor, tendo informado que esta circunstância limitou a participação deles no acompanhamento do julgamento do processo. Dentre os 9 casos em que houve tentativa de entrevista e recusa de participação pelos familiares, em 2 casos eles expressamente afirmaram que não participariam por ainda terem medo do agressor. Por outro lado, em outros casos o acompanhamento dos familiares pelo PROVID deu-lhes maior segurança para acompanharem o processo (por exemplo, os familiares de Rafaela). 
Finalmente, deve-se ter o cuidado de não expor desnecessariamente a intimidade de outras pessoas no curso da investigação criminal. No processo judicial do feminicídio de Melissa, houve encaminhamento pela secretaria de saúde de ofício coletivo com nomes de diversos pacientes e informações de extração de projéteis de arma de fogo. Portanto, houve exposição desnecessária da intimidade dos pacientes em outros processos judiciais.

\subsection{A perícia sobre a violência brutal em áreas erógenas}

As lesões nas regiões erógenas e a agressividade na destruição do corpo da vítima são informações importantes para se reconstruir o recorte de gênero dos feminicídios, pois são expressão da ideia de posse sexual e de destruição da feminilidade (MACHADO, 2015; ONU MULHERES; BRASIL, 2016). Esta atrocidade representa uma espetacularização da violência contra as mulheres, indicando que não basta ceifar a vida, é necessário aniquilar a existência feminina (BANDEIRA, 2017).

Em um caso, observou-se uma falha neste esclarecimento. No caso de Nicole, houve 68 facadas e golpes de martelo por todo o corpo, inclusive nos seios e na região pélvica, conforme fotografias constantes dos autos, mas o laudo do IML não destaca especificamente este ponto, apenas consta do laudo "lesões nos membros superiores". Também não indicou as lesões por martelo praticadas contra a vítima, apenas o laudo do Instituto de Criminalística (IC) fez menção às lesões na região pélvica e lesões por martelo. Portanto, este caso sinaliza a conveniência de que o laudo do IML seja explícito na descrição de lesões com recorte de gênero e haja melhor convergência de critérios técnicos nas perícias do IML e a do IC.

Em diversos outros casos houve adequada explicitação deste contexto nos laudos periciais. Em alguns casos, a extensão das lesões simboliza uma destruição do corpo. Clara recebeu 21 facadas em diferentes partes do corpo, sendo seis na cabeça, duas no pescoço, e quatro no peito. Isadora recebeu 23 golpes de faca em diversas partes do corpo. Rafaela recebeu 20 facadas pelo corpo. Isabela recebeu 40 facadas, inclusive nas costas.

Em outros casos, é a queimadura que possui este significado de destruição. No caso de Sofia, houve queimadura na região pélvica em contexto de possível violência sexual anterior à morte. No caso de Eduarda, o agressor queimou o cadáver e laudo cadavérico indica sinais de possível violência sexual após a morte.

Em outros contextos foi a extensão temporal. Lívia foi espancada durante um período de 15 a 20 minutos, com lesões de elevada extensão corporal, indicando que a destruição do corpo era uma tortura como punição à suposta traição. Finalmente, em outros há o menosprezo: o agressor de Mariana a estrangulou e posteriormente jogou o corpo da vítima em bueiro em via pública. 
A brutalidade destes casos e sua associação com a violência sexual é indicativa da destruição da feminilidade implícita nas mortes. Como a pesquisa analisou apenas os documentos dos autos, não foi possível avaliar se os debates orais em plenário do júri exploraram este aspecto. Pesquisa de Pires (2018, p. 204) quanto a julgamentos plenários de júri de feminicídios no DF documentou que ainda "persiste o uso de estereótipos de gênero tanto por parte da acusação quanto pela defesa". Este é um ponto sensível à justiça do julgamento de feminicídios: trazer à tona as razões de gênero subjacentes às mortes para o julgamento ter também uma função social de reflexão coletiva quanto à inaceitabilidade da discriminação às mulheres.

\subsection{Atuação processual do Ministério Público}

Convém que o Ministério Público tenha atenção mais acurada com a descrição e tipificação das qualificadoras. Por exemplo, no caso de Mariana, o Ministério Público descreveu na denúncia a conduta de dissimulação, mas não a capitulou, sendo que posteriormente o juiz reconheceu de ofício a dissimulação na pronúncia. Seria conveniente sempre haver a tipificação explícita, para se evitar omissões. No caso de Eduarda, o réu foi denunciado por feminicídio com a qualificadora de motivo torpe (ciúmes) e por vilipêndio de cadáver, tendo sido condenado ao final do processo a 22 anos e 2 meses de reclusão. Todavia, neste caso, o agressor abordou a vítima de surpresa dentro de sua casa, com golpes na nuca; portanto, seria possível ter incluído a qualificadora do recurso que dificultou defesa.

Uma das áreas que se afiguram como críticas para a atuação do Ministério Público é a conceituação de "violência baseada no gênero" para fins de tipificação da conduta como feminicídio. O TJDFT possui alguns precedentes reconhecendo que conflitos relacionados a uso abusivo de álcool ou disputas patrimoniais excluiriam a "violência baseada no gênero" (DISTRITO FEDERAL, 2017 e 2019) $)^{15}$. Todavia, estes precedentes estão desalinhados com diretrizes internacionais (ONU, 1992, item 23) e com estudos da sociologia (MACHADO, 2016). O Núcleo de Gênero do MPDFT possui diretriz indicando que todas as violências contra a mulher no âmbito das relações de família, coabitação ou relações íntimas de afeto são formas de violência baseada no gênero, na mesma linha de diretrizes internacionais (TÁVORA; ÁVILA, 2019). A pesquisa

\footnotetext{
${ }^{15}$ Conferir trechos: "Não evidenciada a vinculação entre as ações perpetradas pelo réu com o objeto tutelado pela norma, na medida em que as condutas não impregnaram conteúdo próprio de imposição do padrão masculino sobre o feminino. Desentendimento que decorre da situação patrimonial desencadeada pela dissolução da união, não estando satisfatoriamente caracterizada a motivação de gênero" (DISTRITO FEDERAL, 2019); “A Lei Maria da Penha foi criada para coibir e prevenir a violência doméstica e familiar contra a mulher. Para atrair a lei especial, a ação ou omissão deve ser baseada no gênero. No caso, as agressões não foram motivadas pela condição de vulnerabilidade, hipossuficiência e subordinação da vítima mulher, mas por simples discussão entre irmãos, potencializada pela ingestão de drogas e álcool” (DISTRITO FEDERAL, 2017).
} 
documentou que a controvérsia, que está instalada nos casos de violência doméstica em geral, começa a ingressar nos casos de feminicídio.

Por exemplo, no julgamento do feminicídio de Clara, se tratava de indiscutível relação de convivência com violência crônica, inclusive com a confissão do réu quanto à prática do feminicídio. A defesa argumentou que a presença desta qualificadora não seria presumida em razão da relação de convivência, o que ensejou o reconhecimento da qualificadora do feminicídio pelo jurados por apertado quórum de 4 votos favoráveis à qualificadora e 3 votos contrários. Entre os pontos discutidos no plenário do júri, destacam-se a suspeita de suposta traição por parte da vítima e o não cumprimento do seu papel materno em relação às filhas do relacionamento anterior.

Em um único caso, o de Beatriz, houve a exclusão da qualificadora do feminicídio no julgamento plenário do júri, fixando-se a pena em 6 anos de reclusão em regime semiaberto por homicídio simples. $\mathrm{O}$ autor do feminicídio mantivera relação de namoro com Beatriz por cerca de 5 meses, com contatos esporádicos após o término da relação, e a matou ao encontrá-la em via pública com o novo namorado. Ele era policial militar e sua defesa foi patrocinada por advogado particular. Não consta dos autos os argumentos utilizados na discussão oral no plenário do júri, mas é possível levantar a hipótese de que a operação genderizada do sistema de justiça, identificada por pesquisas anteriores em casos de feminicídio (DINIZ, 2015; MACHADO, 2015; PIRES, 2018), pode ter sido reforçada por marcadores de classe e raça neste caso específico, tendo em vista o status de militar do agressor, o recurso a advogado particular, a possível crítica sexista ao comportamento da vítima e o contexto de relação afetiva intermitente, conferindo um tratamento mais benéfico em comparação com outros casos, com pena desproporcionalmente baixa. Estes dois casos permitem problematizar os riscos de relativização do conceito de violência baseada no gênero para a realização da justiça.

Finalmente, convém que o Ministério Público tenha uma postura ética durante a realização da sustentação oral em plenário do júri, evitando argumentos que possam ofender o direito à memória da vítima ou venham reforçar estereótipos de discriminação às mulheres, bem como zelando para que os demais atores processuais respeitem este paradigma ético. Neste sentido, consta das diretrizes de atuação do MPDFT: "O Promotor de Justiça não deverá indagar às vítimas e/ou testemunhas acerca do comportamento sexual, vestimentas e estilo de vida da vítima, a fim de evitar julgamentos de valor que levem a sua culpabilização pelo crime" (ÁVILA, 2016, p. 18). Todavia, a pesquisa verificou que, no caso de Lívia, consta da ata que o Ministério Público indagou a uma das testemunhas ouvidas em plenário do júri se a vítima era "dada a farras", o que traz implícito um julgamento moral da vítima que deveria ser evitado, por replicar estereótipos de gênero, conforme já referido na Recomendação n. 33/2015 do Comitê CEDAW (ONU, 2015). 
Finalmente, considerando que há diversas especificidades na sustentação da acusação em julgamento plenário do júri em casos de feminicídio, a pesquisa indica a relevância de que a realização destes atos processuais pelos membros do Ministério Público seja sempre antecedida de realização de curso de formação específica. Especialmente quando se trata de Promotores de Justiça Adjuntos recém ingressos na carreira.

\section{Considerações finais}

A análise do fluxo processual dos casos de feminicídio do DF indica um progressivo afunilamento entre as fases de investigação, acusação, pronúncia, julgamento e trânsito em julgado.

$\mathrm{Na}$ amostra original de 44 investigação iniciada como feminicídio, em apenas dois casos não houve esclarecimento da autoria no IP. Dentre os 34 casos de feminicídio em contexto de VDFCM, todos com autoria esclarecida na investigação, em apenas 5 casos não houve ajuizamento de denúncia, em razão do suicídio do agressor. Dentre os casos denunciados, apenas 5 não avançaram para a sentença de pronúncia, sendo a causa mais comum o fato de o réu se tornar foragido, estando pendente de cumprimento o mandado de prisão preventiva. Em nenhum caso houve impronúncia ou absolvição sumária. Dentre os casos julgados em plenário de júri, em apenas um caso houve absolvição imprópria com aplicação de medida de segurança, todos os demais tiveram condenação. Dentre os casos com condenação, em apenas um caso houve o afastamento da qualificadora do feminicídio, com condenação em homicídio simples. A pena média foi de 20 anos de reclusão. O tempo médio do fato ao julgamento plenário do júri foi de 694 dias. Em 91\% dos casos o réu estava preso no momento do julgamento plenário do júri.

Apesar da aparente taxa da efetividade nas condenações, não há uma prática padronizada no Ministério Público de se formular requerimento na denúncia de indenização em favor da vítima e, mesmo quando o pedido é eventualmente formulado, ele não é usualmente aceito pelo Judiciário.

A partir das considerações do presente artigo, é possível apresentar as seguintes recomendações de aperfeiçoamento da atuação processual do Ministério Público em casos de feminicídio:

- Convém uniformizar a prática de se formular requerimento de indenização em favor de familiares da vítima nas denúncias, diligenciando-se no curso do feito a individualização de possíveis beneficiários.

- A investigação criminal deve incorporar a perspectiva de gênero, enquanto metodologia de reconstrução da narrativa dos fatos segundo a compreensão da complexidade das relações de poder subjacentes às violências contra as mulheres.

- A investigação criminal deve ir além do esclarecimento da autoria e materialidade, para incorporar o esclarecimento do contexto relacional que levou ao feminicídio e seus fatores de risco, de forma 
a possibilitar a produção de informações que subsidiem a construção de políticas públicas de prevenção.

- É necessário aprimorar as informações sobre raça/cor da vítima e agressor nos autos dos processos. Sugere-se adequado registro da informação no prontuário de identificação civil da PCDF.

- A perícia criminal deve melhor retratar os vestígios de violências de gênero na cena do crime, como lesões em áreas erógenas, excesso de agressividade para destruição da feminilidade da vítima, coleta de material vaginal para pesquisa de presença de espermatozoides e respectiva juntada aos autos do resultado do exame, perícia na residência da vítima para documentar vestígios de destruição de objetos.

- É recomendável que a investigação criminal realize entrevistas com vizinhos, familiares e amigas da vítima, a fim de carrear aos autos o histórico de violências anteriores pela vítima.

- Deve-se sempre juntar aos autos os boletins de ocorrência policial e eventuais sentenças penais condenatórias relacionadas a episódios de violência doméstica anteriormente praticados pelo réu, contra vítima ou parceira anterior. Deve-se avaliar a conveniência de se ouvir eventual companheira anterior do réu que já tenha sofrido atos semelhantes de violência doméstica.

- É conveniente a realização de estudos psicossociais post mortem pelo setor psicossocial do MPDFT, bem como o esclarecimento quanto à existência de outros estudos psicossociais da vítima em processos anteriores.

- Convém requisitar informações do prontuário médico da vítima da rede pública de saúde, para esclarecer eventuais sinais de violência doméstica anteriores, mesmo sem prévio registro de ocorrência policial.

- As autoridades de persecução penal devem incorporar estratégias para promover a proteção dos familiares da vítima, como o encaminhamento ao programa PROVID da PMDF.

- O Ministério Público deve zelar pela efetiva inclusão na denúncia das qualificadoras que sejam possíveis, além do feminicídio, diante do quadro probatório existente.

- O Ministério Público deve ter uma postura ética durante os julgamentos de feminicídio, não realizando perguntas ou utilizando argumentações que repliquem estereótipos de discriminação às mulheres.

- O Ministério Público deve utilizar o conceito de violência de gênero constante das recomendações de organismos vinculados a tratados internacionais ratificados pelo Brasil, firmando o entendimento de que todas as formas de violência doméstica, familiar e íntima de afeto contra as mulheres são formas de violência baseada no gênero, para fins de tipificação da qualificadora do feminicídio. É necessária capacitação continuada e adequada para que seus membros possam traduzir no processo estas diretrizes. 


\section{Referências}

ÁVILA, Thiago Pierobom de (Coord.). Guia de boas práticas de atuação do promotor de Justiça do júri em casos de feminicídio. Brasília: MPDFT, 2016.

ÁVILA, Thiago Pierobom de. The criminalization of femicide. In: FITZ-GIBBON, Kate; WALKLATE, Sandra; MCCULLOCH, Jude; MAHER, JaneMaree (Eds.). Intimate partner violence, risk and security: securing women's lives in a global world. Londres: Routledge, 2018, p. 181-198.

BANDEIRA, Lourdes Maria. Violência, gênero e poder: múltiplas faces. In: STEVENS, Cristina et al. (Orgs.). Mulheres e violências: interseccionalidades. Brasília: Technopolitik, 2017, p. 14-35.

BRASIL (Secretaria de Políticas para as Mulheres); COPEVID (Comissão Nacional de Promotores de Justiça de Violência Doméstica); COMJIB (Conferência de Ministros da Justiça Iberoamericanos). Diretrizes nacionais de investigação criminal com perspectiva de gênero: princípios para atuação com perspectiva de gênero para o ministério público e a segurança pública do Brasil. Madri: EuroSociAL, 2016.

BRASIL. Comissão Parlamentar Mista de Inquérito sobre Violência contra a Mulher: relatório final. Brasília: Senado Federal, 2013. Disponível em: <https://www12.senado.leg.br/institucional/omv/entenda-a-violencia/pdfs/relatorio-final-dacomissao-parlamentar-mista-de-inquerito-sobre-a-violencia-contra-as-mulheres $>$. Acesso em: 08 maio 2020.

BRASIL. Decreto $n$. 1.973, de $1^{\circ}$ de agosto de 1996. Aprova a Convenção Interamericana para Prevenir, Punir e Erradicar a Violência contra a Mulher, aprovada em Belém do Pará em 1994.

BRASIL. Manual de atuação das promotoras e dos promotores de justiça em casos de feminicídio. Brasília: CNMP, 2019.

BRASIL. Portaria n. 340, de 22 jun. 2020. Cria o Protocolo nacional de investigação e perícia nos crimes e feminicídio. Brasília: Ministério da Justiça e Segurança Pública, 2020.

BRASIL. Relatórios ENASP: dados sobre inquéritos que apuram crimes de feminicídio instaurados entre 10/03/2015 a 10/03/2016. Brasília: CNMP, 2016. Disponível em: <https://www.cnmp.mp.br/portal/component/content/article/101-institucional/enasp/212-enasp1>. Acesso em: 13 maio 2020.

BRASIL. Superior Tribunal de Justiça. REsp 1643051/MS, rel. Min. Rogerio Schietti Cruz, $3^{\text {a }}$ S., j. 28 fev. 2018.

BRAUN, Virginia; CLARKE, Victoria. "Using thematic analysis in psychology". Qualitative Research in Psychology, v. 3, n. 2, p. 77-101, 2006. 
CEPAL - Comissão Econômica para a América Latina e o Caribe. Gender Equality Observatory for Latin America and the Caribbean. Femicide or feminicide as a specific type of crime in national legislations in Latin America: an on-going process. Notes for Equality, n. 17, 2015. Disponível em: <oig.cepal.org/sites/default/files/noteforequality_17_0.pdf> . Acesso em 13 maio 2020.

CIDH - Corte Interamericana de Direitos Humanos. Gonzalez e outras vs. México. Série C, n. 205, 2009.

DINIZ, Debora (Coord.). Radiografia dos homicídios por violência doméstica contra a mulher no Distrito Federal. Brasília: ANIS, 2015.

DINIZ, Debora; COSTA, Bruna Santos; GUMIERI, Sinara. "Nomear feminicídio: conhecer, simbolizar e punir”. Revista Brasileira de Ciências Criminais, v. 114, n. 23, 2015, p. 225-239.

DISTRITO FEDERAL. Norma de Serviço n. 04/2017 da CGP. Boletim de Serviço, n. 46. Brasília: CGP/PCDF, 2017a, p. 1-15.

DISTRITO FEDERAL. TJDFT. Acórdão 1026399, APC-20140610161986APR, rel. Des. Sandra de Santis, $1^{\text {a }}$ T. Crim., j. 8 jun. 2017 b.

DISTRITO FEDERAL. TJDFT. Acórdão 1204483, CC-07180041420198070000, rel. Des. Mario Machado, Câm. Crim., j. 30 set. 2019.

DISTRITO FEDERAL. TJDFT. Acórdão 904781, 20150310069727RSE, rel. Des. George Lopes, $1^{\text {a }}$ T. Crim., j. 29 out. 2015.

FBSP (Org.). Práticas de enfrentamento à violência contra as mulheres: experiências desenvolvidas pelos profissionais de segurança pública e do sistema de justiça. São Paulo: FBSP, 2019.

GODOY, Arilda Schmidt. "Pesquisa qualitativa: tipos fundamentais". Revista de Administração de Empresas, v. 35, n.3, 1995, p 20-29.

GROSSI, Patrícia Krieger; SPANIOL, Marlene Inês. Patrulhas Maria da Penha no Estado do Rio Grande do Sul: análise dos avanços e desafios dos cinco anos da experiência pioneira desta política pública de prevenção à violência de gênero. In: PASINATO, Wania et al. (Orgs.). Políticas públicas de prevenção à violência contra a mulher. São Paulo: Marcial Pons, 2019, p. 298-328.

IPEA; FBSP. Atlas da violência 2019. Brasília: IPEA, FBSP, 2019. Disponível em: $<$ https://www.ipea.gov.br/portal/images/stories/PDFs/relatorio_institucional/190605_atlas_da_vio lencia_2019.pdf>. Acesso em: 01 jun. 2020.

LAGARDE y de Los Ríos, Marcela. "Del femicidio al feminicidio". Desde el Jardin de Freud, n. 6, p. 216-225, 2006.

LEAL, Lourdes Godínez. "Combating impunity and femicide in Ciudad Juarez". NACLA Report on the Americas, v. 41, n. 3, 2008, p. 31-33. 
MACHADO, Lia Zanotta. "Féminicide: nommer pour exister". Brésil( $s$ ) [online], n. 16, 2019, p. 124. Disponível em: 〈https://journals.openedition.org/bresils/5576>. Acesso em: 25 maio 2020.

MACHADO, Lia Zanotta. "Violência baseada no gênero e a Lei Maria da Penha". In: BARBOSA, Thereza Karina de Figueiredo Gaudêncio (Org.). A mulher e a justiça: a violência doméstica sob a ótica dos direitos humanos. Brasília: AMAGIS, 2016, p. 163-175.

MACHADO, Marta Rodriguez de Assis (Coord.). Violência doméstica fatal: o problema do feminicídio íntimo no Brasil. Brasília: Ministério da Justiça, Secretaria da Reforma do Judiciário, 2015.

NIELSSON, Joice Graciele; DELAJUSTIN, Ana Claudia . "A dimensão pública da violência de gênero e a inscrição política do corpo como território: muito mais do que 'briga de marido e mulher'”. Quaestio Iuris, v. 13, n. 01, 2020, p. 322-347.

OLIVEIRA, Marcus Vinicius Berno N. de; MACHADO, Bruno Amaral. "O fluxo do sistema de justiça como técnica de pesquisa no campo da segurança pública". Revista Direito \& Práxis, v. 9, n. 2, 2018, p. 781-809.

OMS - ORGANIZAÇÃO MUNDIAL DE SAÚDE. Relatório mundial sobre violência e saúde. Genebra: OMS. 2002.

ONU - Organização das Nações Unidas. Taking Action Against Gender-related Killing of Women and Girls. $\quad 2014.2$ Disponível em: <www.unodc.org/documents/commissions/CCPCJ/Crime Resolutions/20102019/2013/General Assembly/A-RES-68-191.pdf>. Acesso em: 13 maio 2020.

ONU MULHERES; BRASIL. Diretrizes nacionais feminicídio: investigar, processar e julgar com perspectiva de gênero as mortes violentas de mulheres. Brasília: ONU, SPM/PR e Senasp/MJ, 2016. Disponível em: $\quad$ http://www.onumulheres.org.br/wp-content/uploads/2016/04/diretrizes feminicidio.pdf>. Acesso em 06 jun. 2020.

ONU. Comitê CEDAW, Recomendação Geral n. 19 (sobre a violência contra as mulheres), 1992. Disponível em: 〈https://www.ohchr.org/EN/HRBodies/CEDAW/Pages/Recommendations.aspx $>$. Acesso em 29 jun. 2018.

ONU. Comitê CEDAW, Recomendação Geral n. 33 (sobre o acesso das mulheres à justiça), 2015. Disponível em: 〈https://www.ohchr.org/EN/HRBodies/CEDAW/Pages/Recommendations.aspx > Acesso em: 13 maio 2020.

PASINATO, Wânia. “Femicídios' e as mortes de mulheres no Brasil”. Cadernos Pagu, n. 37, 2011, p. 219-246.

PIRES, Amom Albernaz. O feminicídio no Código Penal Brasileiro: da nomeação feminista às práticas jurídicas no plenário do júri. Dissertação (Mestrado) - Faculdade de Direito, Universidade de Brasília. 2018. 
QUIÑONES, Adriana. Take five: fighting femicide in Latin America. 2017. Disponível em: <www.unwomen.org/en/news/stories/2017/2/take-five-adriana-quinones-femicide-in-latinamerica>. Acesso em: 13 maio 2020.

ROMERO, Teresa Incháustegui. "Sociología y política del feminicídio: algunas claves interpretativas a partir de caso mexicano". Revista Sociedade e Estado, v. 29, n. 2, 2014, p. 373400 .

RUSSELL, Diana E. H. Preface. In: RADFORD, Jill; RUSSELL, Diana E.H. (Orgs.) Femicide: the politics of women killing. Nova Iorque: Twayne Publisher, 1992, p. xi-xv.

SEGATO, Rita Laura. "Que és Feminicidio: notas para un debate emergente". Série Antropológica do Departamento de Antropologia da Universidade de Brasília, n. 401, 2006, p. 1-11.

SILVA, Artenira da Silva e; MANSO, Almudena García; PINHEIRO, Rossana Barros. "Violencia contra la mujer como mal endémico en la sociedad contemporánea". Quaestio Iuris, v. 12, n. 1, 2019, p. 144-170.

SMALL ARMS SURVEY. “A gendered analysis of violent deaths". Small Arms Survey Research Note, n. 63, 2016, p. 1-8. Disponível em: <http://www.smallarmssurvey.org/fileadmin/docs/HResearch Notes/SAS-Research-Note-63.pdf>. Acesso em: 13 maio 2020.

TAVARES, Regina Lúcia Gonçalves; SILVA, Artenira da Silva e. "Percepção disfuncional do agressor na Lei Maria da Penha: tolerância e invisibilidade num sistema de continuidades". Quaestio Iuris, v. 10, n. 03, 2017, p. 2031-2059.

TÁVORA, Mariana Fernandes; ÁVILA, Thiago Pierobom de (Orgs.). Roteiro de boas práticas para promotoras/es de Justiça de violência doméstica e familiar contra as mulheres. $2^{\mathrm{a}}$ ed. Brasília: MPDFT, 2019.

\section{AGRADECIMENTOS}

A presente pesquisa foi realizada pela Escola Superior do Ministério Público da União (Edital de pesquisa acadêmica n. 1129/2017), com apoio logístico do Núcleo de Gênero do Ministério Público do Distrito Federal e Territórios e supervisão externa do Instituto ANIS. Não houve conflito de interesse a comprometer a cientificidade do trabalho. Além dos autores, integraram a equipe de pesquisa Cátia Betânia Chagas e Elaine Novaes Vieira. Os autores agradecem às colaborações de Mariana Távora, Amom Albernaz Pires, Raoni Parreira Maciel, René Mallet Raupp e Débora Diniz.

Trabalho recebido em 30 de outubro de 2020 Aceito em 30 de Julho de 2021 